Current Topics

\title{
Recent Progress in Medicinal Chemistry
}

\section{Review \\ New Gateways to the Platinum Group Metal-Catalyzed Direct Deuterium-Labeling Method Utilizing Hydrogen as a Catalyst Activator}

\author{
Yoshinari Sawama,* Kwihwan Park, Tsuyoshi Yamada, and Hironao Sajiki* \\ Laboratory of Organic Chemistry, Gifu Pharmaceutical University; \\ 1-25-4 Daigaku-nishi, Gifu 501-1196, Japan. \\ Received March 15, 2017
}

\begin{abstract}
Deuterium-labeled compounds are widely utilized in various scientific fields. We summarize the recent advances in the direct deuteration of sugar, saturated fatty acid, and arene derivatives using heterogeneous platinum group metal on carbon catalysts by our research group. Hydrogen gas is a key catalyst-activator to facilitate the present $\mathrm{H}-\mathrm{D}$ exchange reactions. In this review, the direct activation method of catalysts using in situ-generated hydrogen based on the dehydrogenation of alcohols is introduced. The obtained multiple deuterium-labeled products, including bioactive compounds, are expected to contribute to the development of many scientific investigations.
\end{abstract}

Key words deuterium labeling; heterogeneous catalyst; deuterium oxide; hydrogen; dehydrogenation

\section{Introduction}

Deuterium $\left({ }^{2} \mathrm{H}\right.$ or $\left.\mathrm{D}\right)$ is a stable and safe isotope of hydrogen $\left({ }^{1} \mathrm{H}\right)$, and carbon $(\mathrm{C})-\mathrm{D}$ bonds are known to be stronger than $\mathrm{C}-\mathrm{H}$ bonds due to the isotope effect. Based on these useful properties of $\mathrm{C}-\mathrm{D}$ bonds, deuterium-labeled organic compounds have traditionally been utilized in various scientific fields, such as the elucidation of reaction mechanisms, investigation of metabolism, microanalysis tracers, etc. ${ }^{1-6)}$ Recently, the delay effects of the metabolism of heavy drugs, which are partially deuterium-labeled original drugs, have been in the spotlight. ${ }^{75)}$ Therefore, the development of various preparation methods of deuterium-labeled medicines and synthetic precursors are eagerly awaited in order to contribute to the progress of a wide variety of scientific fields. In this review, we mainly summarize the heterogeneously catalyzed deuteration of alcohols including sugars in $\mathrm{D}_{2} \mathrm{O}$ based on the hydrogen gas $\left(\mathrm{H}_{2}\right)$-activation of metals and $\mathrm{H}-\mathrm{D}$ exchange reactions of arenes and saturated fatty acids along with the in situ generation of the bare essentials of $\mathrm{H}_{2}$ by the dehydrogenation of alcohols.

\section{H-D Exchange Reactions under Hydrogen Atmo-} sphere

2.1. Deuterium Labeling of Various Organic Compounds $\mathrm{H}-\mathrm{D}$ exchange reactions are straightforward and powerful methods to construct the corresponding deuteriumlabeled compounds, and the use of deuterium oxide $\left(\mathrm{D}_{2} \mathrm{O}\right)$ as the cheapest and inexhaustible deuterium source possesses some advantages from the viewpoint of cost performance and environmental harmony. Additionally, heterogeneous metal catalysts, which are easily removed from the reaction media without metal leaching, are appreciated in process chemistry. Although palladium on carbon $(\mathrm{Pd} / \mathrm{C})$ as a representative het- erogeneous catalyst can catalyze the $\mathrm{H}-\mathrm{D}$ exchange reaction in $\mathrm{D}_{2} \mathrm{O}$ to give deuterium-labeled compounds, e.g., arene ${ }^{16)}$ and alkanes, ${ }^{17)}$ harsh reaction conditions $\left(>220^{\circ} \mathrm{C}\right)$ in special pressure-tight vessels are required. Meanwhile, we found that $\mathrm{H}_{2}$ effectively activates the metals, e.g., Pd, Pt, Rh, etc., on carbon, and $\mathrm{H}-\mathrm{D}$ exchange reactions can smoothly proceed in $\mathrm{D}_{2} \mathrm{O}$ under milder reaction conditions (lower temperature and short reaction time $)^{3,5,6)}$ (Chart 1). The deuteration patterns are particularly characteristic depending on the metal of the catalyst. For example, the $\mathrm{Pd} / \mathrm{C}$-catalyzed $\mathrm{H}-\mathrm{D}$ exchange reaction at the benzylic position can proceed site-selectively in $\mathrm{D}_{2} \mathrm{O}$ at room temperature under a hydrogen atmosphere, ${ }^{18)}$ and the $\mathrm{Pd} / \mathrm{C}$ - or Pt/C-catalyzed heating conditions allow the production of the multideuterium-labeled arenes accompanied by the multideuteration of the alkyl side chain connected to the arene nuclei. ${ }^{19)}$ Furthermore, $\mathrm{Rh} / \mathrm{C}$ is an effective catalyst to activate the inactive $\mathrm{C}-\mathrm{H}$ bonds of alkanes and produce multideuterated alkanes. ${ }^{20)}$

In these $\mathrm{H}-\mathrm{D}$ exchange reactions, the zerovalent platinumgroup metal (A) coordinated by $\mathrm{H}_{2}$ and $\mathrm{D}_{2} \mathrm{O}$ is proposed to

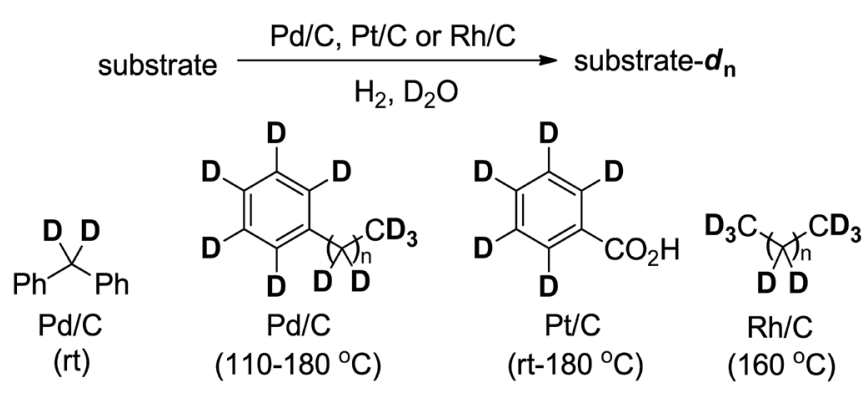

Chart 1. Platinum Group Metal on Carbon-Catalyzed Deuterium Labeling under Hydrogen Atmosphere 


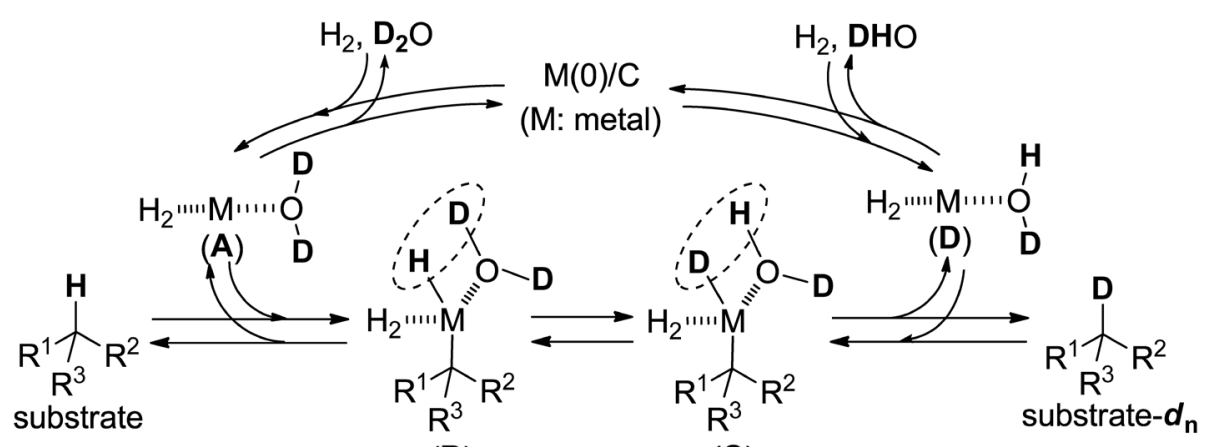

(B)

(C)

Chart 2. Role of Hydrogen and Proposed Reaction Mechanism

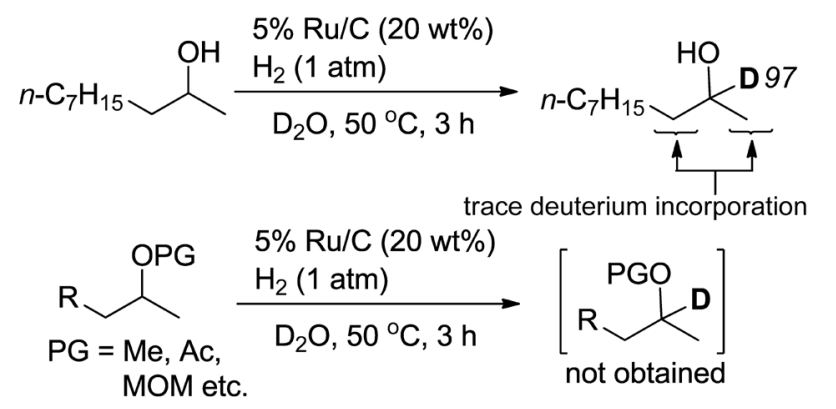

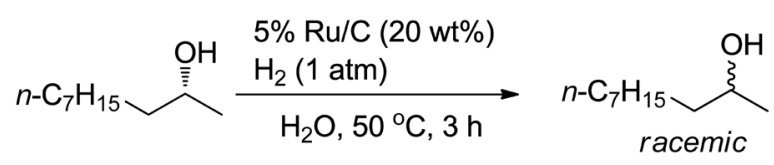

Chart 3. Deuteration of Linear Alcohols

play an important role as an active species (Chart 2). As a plausible mechanism, the $\mathrm{C}-\mathrm{H}$ bond of the substrate undergoes the oxidative addition of the active metal( 0$)$ to generate the metal(II) reaction intermediate (B), on which the $\mathrm{H}-\mathrm{D}$ exchange reaction between a hydrogen atom on the metal and a deuterium on $\mathrm{D}_{2} \mathrm{O}$ takes place to form $\mathbf{C}$. The subsequent reductive elimination gives the deuterium-labeled product (substrate- $d_{1}$ ), and the zerovalent metal catalyst is reproduced. Repeated H-D exchange reactions can produce the multideuterated product (substrate- $d_{n}$ ). Although all the reaction steps are in equilibria, the multideuterated products are preferentially obtained to circumvent the inverse reaction due to the stability of the $\mathrm{C}-\mathrm{D}$ bond in comparison with the $\mathrm{C}-\mathrm{H}$ bond.

2.2. Site-Selective Deuteration of Alcohols and Its Application to the Deuteration of Sugars ${ }^{21,22)}$ Secondary and primary alcohols are deuterium-labeled site-selectively at the $\alpha$-position of the hydroxy groups using $\mathrm{Ru} / \mathrm{C}{ }^{21)}$ For example, 2-decanol efficiently undergoes $\mathrm{Ru} / \mathrm{C}$-catalyzed monodeuteration in $\mathrm{D}_{2} \mathrm{O}$ at $50^{\circ} \mathrm{C}$ under a hydrogen atmosphere for $3 \mathrm{~h}$ to give 2-decanol- $d_{1}$ with a $97 \% \mathrm{D}$ content, along with the incorporation of a trace amount of deuterium atoms at the $\beta$-positions (Chart 3, top). On the other hand, the $\alpha$-position of a protected alcohol, such as a methoxy, acetoxy, or methoxymethyloxy group, is never deuterated under similar reaction conditions (Chart 3, middle). Additionally, chiral (R)-2-decanol is transformed into the corresponding racemate under $\mathrm{Ru} / \mathrm{C}$-catalyzed $\mathrm{H}-\mathrm{H}$ exchange reaction conditions in $\mathrm{H}_{2} \mathrm{O}$ instead of $\mathrm{D}_{2} \mathrm{O}$ (Chart 3, bottom). On the other hand, methyl $\alpha$-D-glucopyranoside as a sugar derivative with low flexibility around each hydroxy group undergoes stereoselec- tive multideuteration at the $\alpha$-positions of each hydroxy group to give methyl $\alpha$-D-glucopyranoside- $d_{5}$ in quantitative $\mathrm{D}$ contents with retention of its configuration ${ }^{22)}$ (Chart 4). (The D contents and yield were determined after acetylation of all the hydroxy groups due to the easy assignments of the ${ }^{1} \mathrm{H}$ and ${ }^{2} \mathrm{H}$ [D] NMR.)

These results clearly indicate that some considerable reaction mechanisms exist for the deuteration of alcohols (Chart 5). The $\mathrm{Ru}(0)$ species (E) activated by $\mathrm{H}_{2}$ and $\mathrm{D}_{2} \mathrm{O}$ is coordinated by the lone pair of the hydroxy group of alcohol to form $\mathbf{F}$, and the subsequent oxidative addition gives a $\mathrm{Ru}(\mathrm{II})$ intermediate $(\mathbf{G})$. Then, the $\mathrm{H}-\mathrm{D}$ exchange reaction $(\mathbf{H})$ and reductive elimination produce a monodeuterated alcohol and $\operatorname{Ru}(0)$ species (I). Alternatively, the dehydrogenation of $\mathbf{F}$ into the corresponding ketone and subsequent hydrogenation by $\mathrm{D}_{2}$ or $\mathrm{DH}$ can give the monodeuterated alcohol $\left(\mathrm{H}_{2}\right.$ can be transformed into $\mathrm{D}_{2}$ by the $\mathrm{Ru}$ in the carbon-catalyzed $\mathrm{H}_{2}-\mathrm{D}_{2}$ exchange reaction). ${ }^{23)}$ The former reaction path via the oxidative addition can proceed with the retention of the configuration, while the racemate is generated via the latter reaction pathway based on the dehydrogenative oxidation process. That is, the flexible and linear alcohols can be deuterated via both pathways with the loss of stereochemistry, and the deuteration of sugar derivatives as stereochemically rigid substrates preferentially proceeds via the former pathway to circumvent the unfavorable strain of the corresponding cyclic ketones as intermediates.

The $\mathrm{Ru} / \mathrm{C}$-catalyzed $\mathrm{H}-\mathrm{D}$ exchange reaction of hydroxy groups can be adopted for various sugar derivatives (Chart 6). A wide variety of sugar derivatives including riboses are effectively deuterium-labeled at the hydroxy $\alpha$-positions, and site-selective deuteration can also be carried out by the preliminary protection of specific hydroxy groups, since the $\alpha$-position of the protected alcohol is never deuterated. Although the deuteration of sugar derivatives using Raney Ni in $\mathrm{D}_{2} \mathrm{O}$ was previously reported, the deuterium efficiency is unsatisfactory and harsh reaction conditions using ultrasonication or microwaves are required. ${ }^{24-32)}$ In contrast, the present method under milder reaction conditions with a wide scope of substrates is useful and valuable to synthesize various types of deuterium-labeled sugars.

\section{Dehydrogenation of Alcohols ${ }^{33,34)}$}

Encouraged by the novel aspect of the proposed reaction mechanisms for the $\mathrm{H}-\mathrm{D}$ exchange reaction of alcohols (Section 2, Chart 5), we have focused on the development 


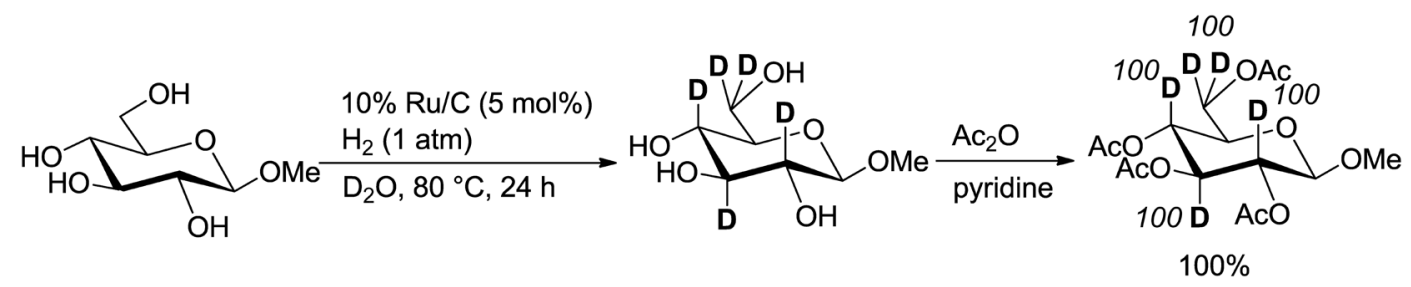

Chart 4. Multi-deuterium Labeling of Methyl $\alpha$-D-Glucopyranoside

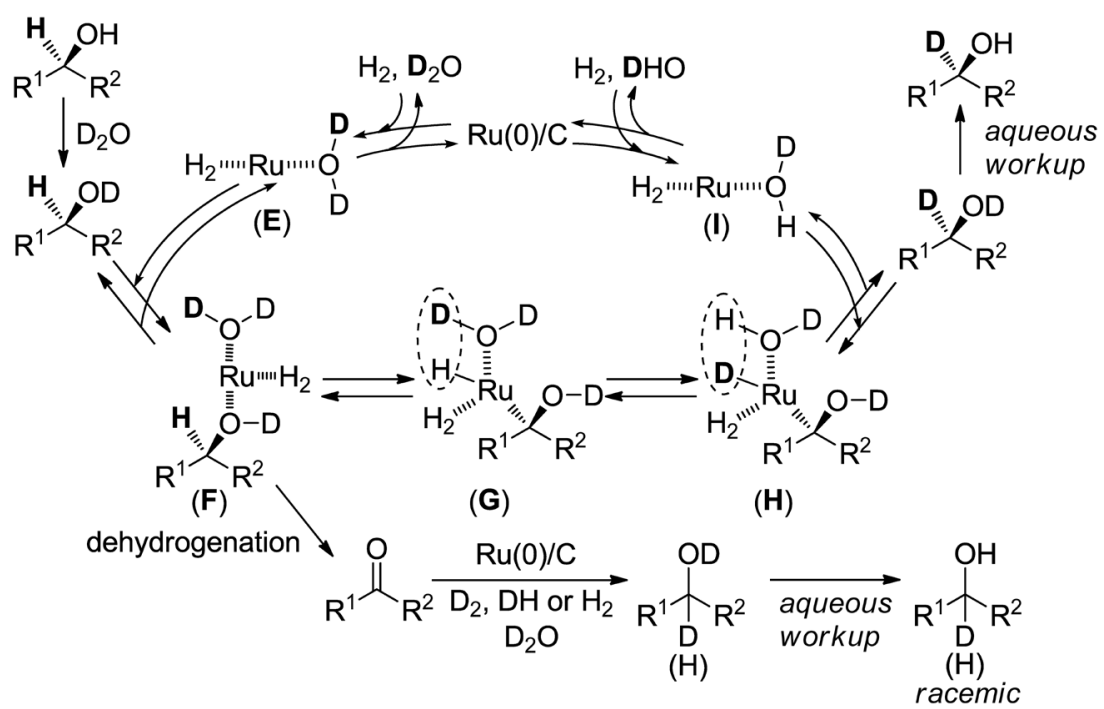

Chart 5. Proposed Reaction Mechanism for H-D Exchange Reaction of Alcohols

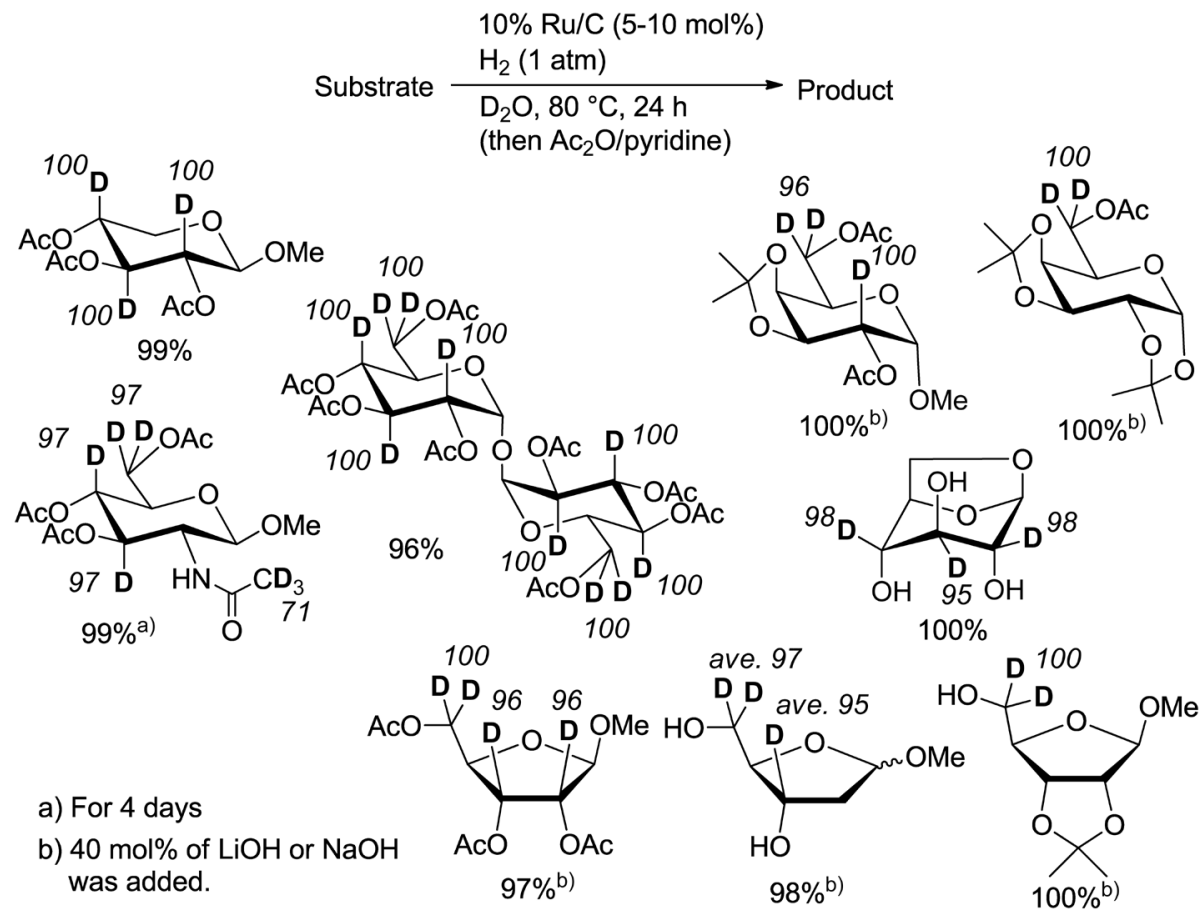

Chart 6. Site-Selective Deuteration of Sugars

of dehydrogenative oxidation of alcohols into carbonyl products. Since the oxidation of alcohols traditionally required toxic and/or explosive oxidizing agents, ${ }^{35)}$ heterogeneously catalyzed dehydrogenation reactions are spotlighted as clean oxidation methods generating only $\mathrm{H}_{2}$ utilized as the reductant in organic synthesis and energy sources. However, organic solvents have been required for the reported methods. ${ }^{36-43)}$ Although the dehydrogenation of alcohols using a platinum group metal on carbon as a catalyst in $\mathrm{H}_{2} \mathrm{O}$ can proceed as shown in Chart 5 to give the intermediary carbonyl products, 


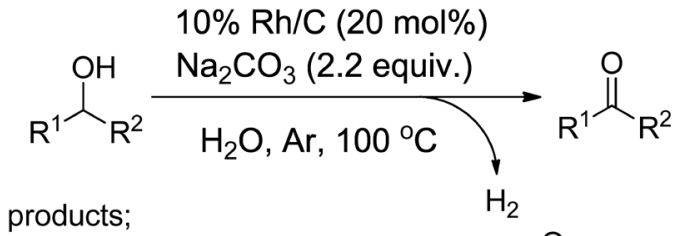<smiles>CCCCC(=O)c1ccccc1</smiles><smiles>CC(C)(C)C(=O)c1ccccc1</smiles>
$81 \%(6 h) \quad 76 \%(48 h)$<smiles>O=C1c2ccccc2-c2ccccc21</smiles><smiles>[R]c1ccc(C(=O)c2ccc([R])cc2)cc1</smiles>

$\mathrm{R}=\mathrm{OMe} ; 89 \%(6 \mathrm{~h})$ $\mathrm{R}=\mathrm{Cl} ; 89 \%(24 \mathrm{~h})$

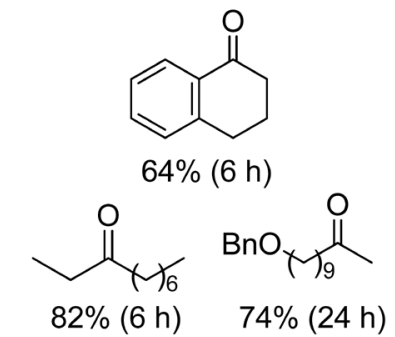

Chart 7. Dehydrogenation of Secondary Alcohols into Ketones

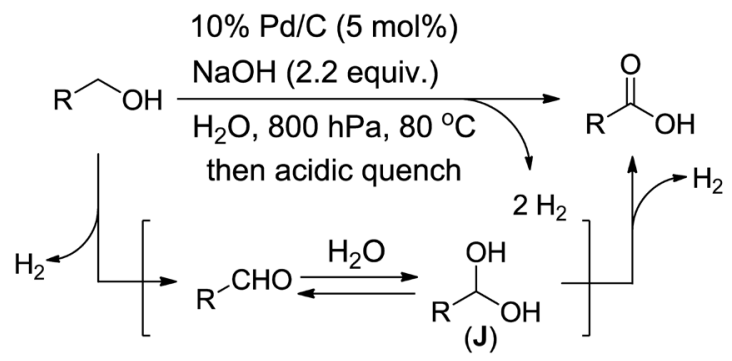

products;
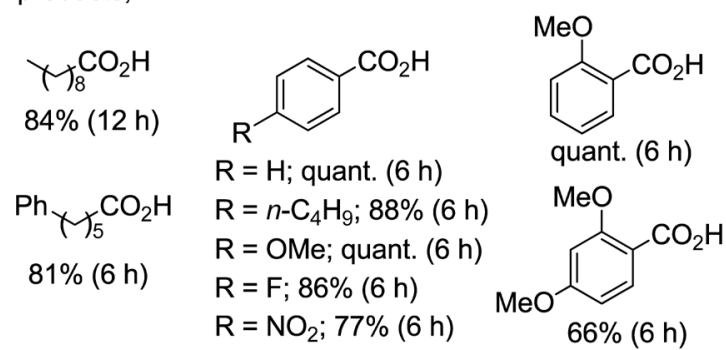

Chart 8. Dehydrogenation of Primary Alcohols under Reduced Pressure into Carboxylic Acids

the reverse hydrogenation by the in situ-generated $\mathrm{H}_{2}$ immediately reproduces the mother alcohols. Therefore, the suppression of the reverse hydrogenation is important to achieve the dehydrogenation of alcohols into carbonyl products. As a result of an in-depth examination, $\mathrm{Rh} / \mathrm{C}$ showing lower activity against the reverse hydrogenation was found to be an adequate catalyst for the dehydrogenation of secondary alcohols under basic aqueous reaction conditions using $\mathrm{Na}_{2} \mathrm{CO}_{3}{ }^{33)}$ (Chart 7). Various secondary aliphatic and benzylic alcohol derivatives are effectively transformed into the corresponding ketones.

Meanwhile, primary alcohols are converted into carboxylic acid derivatives via the $\mathrm{Pd} / \mathrm{C}$-catalyzed double-dehydrogenation steps in $\mathrm{H}_{2} \mathrm{O}$ in the presence of $\mathrm{NaOH}$ (Chart 8). The initial dehydrogenation of primary alcohols gives aldehydes, which are transformed into the corresponding hydrates $(\mathbf{J})$ in $\mathrm{H}_{2} \mathrm{O}$. The subsequent second dehydrogenation of $\mathbf{J}$ produces carboxylic acids. $\mathrm{NaOH}$ probably plays a role to facilitate

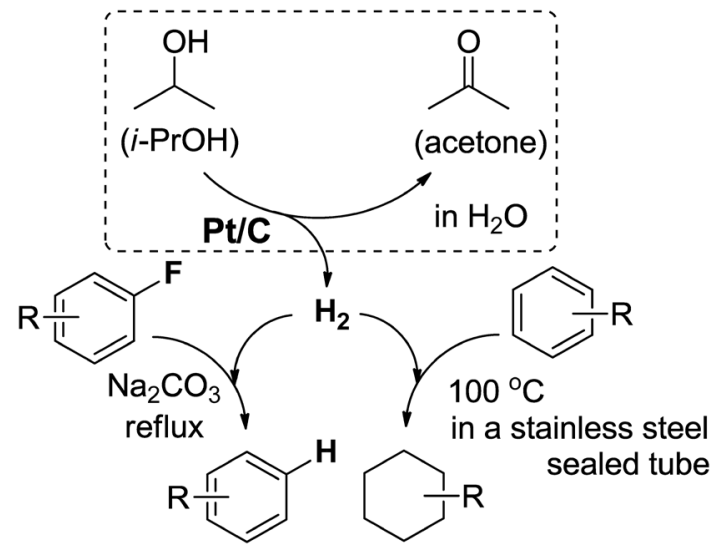

Chart 9. Reduction Using Isopropanol as a Hydrogen Source

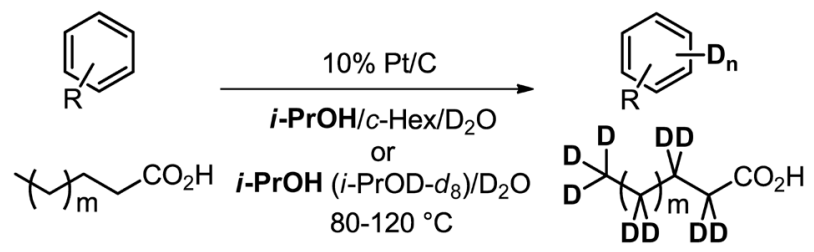

Chart 10. Deuteration Using Isopropanol as the Hydrogen Source

the hydration of aldehydes. However, the in situ-generated $\mathrm{H}_{2}$ during the dehydrogenation of primary alcohols produces some undesired side reactions (e.g., decarbonylation, hydrogenation of aldehyde, etc.). Therefore, the removal of the in situ-generated $\mathrm{H}_{2}$ from the reaction apparatus under slightly reduced pressure ( $c$ a $800 \mathrm{hPa})$ is effective to prevent such side reactions, and various primary aliphatic and benzylic alcohols can be adopted for the $\mathrm{Pd} / \mathrm{C}$-catalyzed dehydrogenation to give the corresponding carboxylic acids in high yields.

According to the results of a dehydrogenation study (Charts 7 and 8), isopropanol can be a convenient, adequate hydrogen source, because the neutral acetone generated as a by-product is also dissolved in $\mathrm{H}_{2} \mathrm{O}$ and barely suppresses the desired reaction. The in situ-generated $\mathrm{H}_{2}$ can be directly utilized in the platinum group metal in the carbon-catalyzed reduction of various substrates (Chart 9). Specifically, aromatic fluorides are effectively defluorinated into arenes using $\mathrm{Pt} / \mathrm{C}$ in a mixed solvent of $\mathrm{H}_{2} \mathrm{O}$ and $i$ - $\mathrm{PrOH},{ }^{44)}$ and the $\mathrm{Pt} / \mathrm{C}$-catalyzed arene reduction also smoothly proceeds in a stainless steel sealed tube. $^{45)}$

\section{H-D Exchange Reaction Using Isopropanol as a Hy- drogen Source}

$\mathrm{H}_{2}$ is an important key activator for the H-D exchange reaction catalyzed by a platinum group metal on carbon (Section 2). The present in situ-generation method of $\mathrm{H}_{2}$ from $i$-PrOH (Chart 9) can also be applied to the $\mathrm{H}-\mathrm{D}$ exchange reaction of arenes ${ }^{46)}$ and carboxylic acids ${ }^{47)}$ using $\mathrm{Pt} / \mathrm{C}^{48)}$ in the mixed solvent of $i-\mathrm{PrOH}$ and $\mathrm{D}_{2} \mathrm{O}$, and the corresponding multideuterated products are efficiently obtained (Chart 10). Since only a tiny but sufficient amount of $\mathrm{H}_{2}$ for the activation of $\mathrm{Pt} / \mathrm{C}$ is generated during the deuteration, the hydrogenation of the coexisting reducible functionalities (e.g., olefin, ketone, etc.) is suppressed. The use of $i-\mathrm{PrOH}$ as a hydrogen source and $\mathrm{D}_{2} \mathrm{O}$ should be adequately screened in order to achieve the H-D exchange reactions of the target substrates, as detailed in Sec- 
tions 4.1 and 4.2 .

4.1. Deuteration of Aromatic Nuclei $^{46)}$ In the H-D exchange reaction of biphenyl $(0.25 \mathrm{mmol})$ using $\mathrm{Pt} / \mathrm{C}$ in the mixed solvent of $i$-PrOH $(2 \mathrm{~mL})$ and $\mathrm{D}_{2} \mathrm{O}(1 \mathrm{~mL})$ at $100^{\circ} \mathrm{C}$ for $24 \mathrm{~h}$, all the $\mathrm{C}-\mathrm{H}$ bonds on the aromatic rings are transformed into $\mathrm{C}-\mathrm{D}$ bonds in $c a$. $80 \% \mathrm{D}$ contents (Table 1, entry 1). Independent use of $\mathrm{D}_{2} \mathrm{O}$ resulted in no deuterium incorporation (entry 2). The use of $\mathrm{MeOH}$ or $t-\mathrm{BuOH}$ as a co-solvent of $\mathrm{D}_{2} \mathrm{O}$ instead of $i-\mathrm{PrOH}$ is extremely inefficient (entries 3 and 4). Because $i$-PrOH can be an efficient hydrogen source to promote the undesired reverse $\mathrm{D}-\mathrm{H}$ exchange reaction resulting in lower D efficiency, the decrease in the use of $i$-PrOH (from $2 \mathrm{~mL}$ to $1 \mathrm{~mL})$ versus $\mathrm{D}_{2} \mathrm{O}(1 \mathrm{~mL})$ significantly increases the $\mathrm{D}$ contents of biphenyl (entry 5). Furthermore, the increment

Table 1. Solvent Effect in Deuteration on Biphenyl as an Arene

\begin{tabular}{|c|c|c|c|c|}
\hline \multirow{2}{*}{ Entry } & \multirow{2}{*}{ Solvent (mL) } & \multicolumn{3}{|c|}{ D Content $(\%)$} \\
\hline & & $\mathrm{a}$ & $\mathrm{b}$ & $\mathrm{c}$ \\
\hline 1 & $i-\mathrm{PrOH} / \mathrm{D}_{2} \mathrm{O}(2 / 1)$ & 79 & 80 & 81 \\
\hline 2 & $\mathrm{D}_{2} \mathrm{O}(1)$ & 0 & 0 & 0 \\
\hline 3 & $\mathrm{MeOH} / \mathrm{D}_{2} \mathrm{O}(2 / 1)$ & 6 & 3 & 9 \\
\hline 4 & $t-\mathrm{BuOH} / \mathrm{D}_{2} \mathrm{O}(2 / 1)$ & 0 & 0 & 0 \\
\hline 5 & $i-\mathrm{PrOH} / \mathrm{D}_{2} \mathrm{O}(1 / 1)$ & 91 & 90 & 91 \\
\hline 6 & $i-\mathrm{PrOH} / \mathrm{D}_{2} \mathrm{O}(1 / 2)$ & 95 & 96 & 96 \\
\hline 7 & $i-\mathrm{PrOH} / \mathrm{D}_{2} \mathrm{O}(0.5 / 2)$ & 93 & 94 & 95 \\
\hline 8 & $i-\mathrm{PrOH} / \mathrm{D}_{2} \mathrm{O}(0.1 / 2)$ & 15 & 34 & 23 \\
\hline 9 & $i-\mathrm{PrOH} / c-$ hex $/ \mathrm{D}_{2} \mathrm{O}(0.1 / 0.9 / 2)$ & 93 & 98 & 98 \\
\hline $10^{a)}$ & $i-\mathrm{PrOH} / c-\mathrm{hex} / \mathrm{D}_{2} \mathrm{O}(0.1 / 0.9 / 2)$ & 97 & 98 & $98(>99 \%)^{b)}$ \\
\hline
\end{tabular}

a) At $80^{\circ} \mathrm{C} . b$ ) Isolated yield. of $\mathrm{D}_{2} \mathrm{O}$ (from 1 to $2 \mathrm{~mL}$ ) also improved the $\mathrm{D}$ efficiency up to ca. $95 \% \mathrm{D}$ contents (entry 6), although the D contents using a lower amount of $i$-PrOH from 1 to 0.5 and $0.1 \mathrm{~mL}$ produced an undesirable result due to the lower solubility of biphenyl in the mixed solvent (entries 7 and 8). However, such inadequacies are easily resolved by the addition of cyclohexane ( $c$-hex) as an auxiliary solvent $\left(i-\mathrm{PrOH} / c-h e x / \mathrm{D}_{2} \mathrm{O}=0.1 / 0.9 / 2 \mathrm{~mL}\right)$ to dissolve the biphenyl, and the $\mathrm{D}$ efficiency is dramatically improved (entry 9). Eventually, the $\mathrm{H}-\mathrm{D}$ exchange reaction effectively proceeds at the reaction temperature of $80^{\circ} \mathrm{C}$ to give nearly quantitative $\mathrm{D}$ contents with quantitative isolated yields (entry 10).

The aromatic nuclei of phenol, benzoic acid, $N$-methyl benzoyl amide, and acetanilide efficiently undergo the $\mathrm{H}-\mathrm{D}$ exchange reaction under $\mathrm{Pt} / \mathrm{C}$-catalyzed reaction conditions using a mixed solvent $\left(i-\mathrm{PrOH} / c-h e x / \mathrm{D}_{2} \mathrm{O}\right)$ to give the corresponding deuterium-labeled products (Chart 11, top line). $n$-Hexylbenzene is also deuterated, accompanied by the deuteration of the alkyl side chain. Substrates bearing reducible functionalities (such as carbonyls and olefins) within the molecule can be deuterated without their reduction to produce useful deuterated synthetic precursors (Chart 11, middle and bottom lines). These transformations cannot be achieved by the previously reported platinum group metal in the carboncatalyzed deuteration method under a $\mathrm{H}_{2}$ atmosphere as shown in Chart 1, which causes the hydrogenation of the carbonyl and olefin functionalities into the corresponding alcohols and alkanes, respectively.

4.2. Deuteration of Saturated Fatty Acids ${ }^{47)}$ Deuterium-labeled saturated fatty acids are utilized in the field of biochemistry. ${ }^{49-68)}$ Although $\mathrm{Pt} / \mathrm{C}$ has been traditionally used in $\mathrm{D}_{2} \mathrm{O}$ for the preparation of deuterium-labeled saturated fatty acids, harsh hydrothermal reaction conditions and repetitive deuteration processes are required, and the D contents and scope of the substrates were unsatisfactory using previously reported methods. ${ }^{69)}$ Since the deuteration of alkanes, such

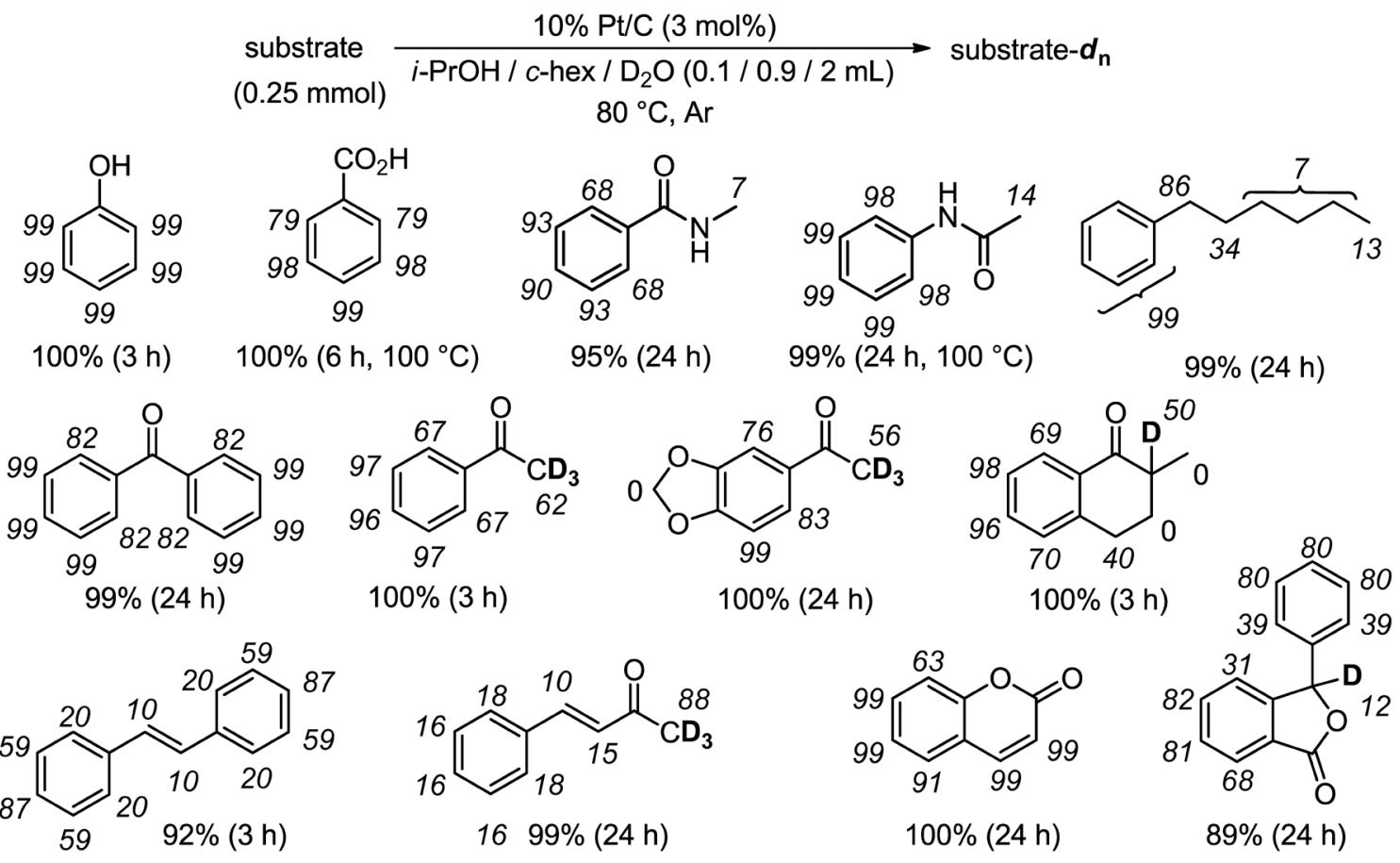

Chart 11. Scope of Substrates for Deuteration of Arenes 


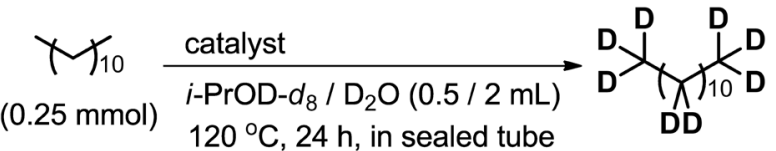

$$
\begin{aligned}
& \text { D contents (\%) } \\
& \begin{aligned}
& \text { catalyst: } 5 \% \mathrm{Rh} / \mathrm{C}(15 \mathrm{~mol} \%) \\
&+10 \% \mathrm{Pt} / \mathrm{C}(15 \mathrm{~mol} \%) ; \mathrm{CD}_{3}: 96, \mathrm{CD}_{2}: 94
\end{aligned} \\
& 10 \% \mathrm{Pt} / \mathrm{C}(30 \mathrm{~mol} \%) ; \quad \mathrm{CD}_{3}: 90, \mathrm{CD}_{2}: 91
\end{aligned}
$$

Chart 12. Deuteration of Dodecane as an Alkane

Table 2. Solvent Effect on Deuteration of Capric Acid as a Saturated

\begin{tabular}{|c|c|c|c|c|c|}
\hline \multirow{2}{*}{ Entry } & \multirow{2}{*}{ Solvent (mL) } & \multicolumn{4}{|c|}{ D Content $(\%)$} \\
\hline & & $\mathrm{a}$ & $\mathrm{b}$ & $\mathrm{c}$ & $\mathrm{d}$ \\
\hline 1 & $i-\mathrm{PrOH} / \mathrm{D}_{2} \mathrm{O}(0.5 / 2)$ & 89 & 90 & 93 & 92 \\
\hline 2 & $i-\mathrm{PrOH} / \mathrm{D}_{2} \mathrm{O}(0.5 / 3)$ & 96 & 95 & 92 & $94(93 \%)^{b)}$ \\
\hline 3 & $i-\mathrm{PrOH}-d_{8} / \mathrm{D}_{2} \mathrm{O}(0.5 / 2)$ & 98 & 99 & 96 & $94(96 \%)^{b)}$ \\
\hline 4 & $i-\mathrm{PrOH}-d_{8} / \mathrm{D}_{2} \mathrm{O}(0.25 / 1)$ & 38 & 49 & 57 & 66 \\
\hline 5 & $i-\mathrm{PrOH}-d_{8} / \mathrm{D}_{2} \mathrm{O}(0.1 / 2)$ & 32 & 51 & 58 & 61 \\
\hline 6 & $\mathrm{D}_{2} \mathrm{O}(2)$ & 13 & 13 & 9 & 18 \\
\hline 7 & $\mathrm{CD}_{3} \mathrm{OD} / \mathrm{D}_{2} \mathrm{O}(0.5 / 2)$ & 8 & 8 & 5 & 8 \\
\hline
\end{tabular}
Fatty Acid

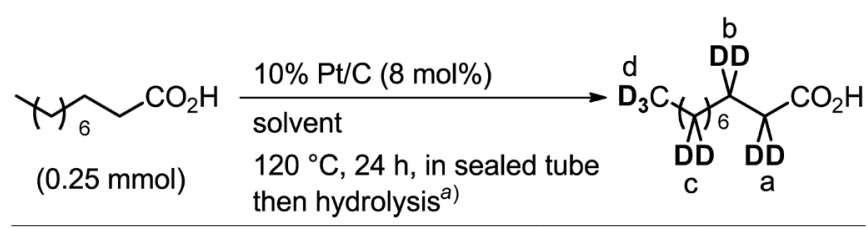

a) Isolated after hydrolysis of the generated isopropyl ester using 5 equiv. of $\mathrm{NaOH}$ at $70^{\circ} \mathrm{C}$ for $24 \mathrm{~h} . b$ ) Isolated yield.

as $c$-hex, was found to proceed under $\mathrm{Pt} / \mathrm{C}$-catalyzed reaction conditions in $i$ - $\mathrm{PrOH} / \mathrm{D}_{2} \mathrm{O}$ at $120^{\circ} \mathrm{C}$ (Chart 12), ${ }^{70)}$ we chose a mixed solvent of $i-\mathrm{PrOH}$ and $\mathrm{D}_{2} \mathrm{O}$ to circumvent the use of $c$-hex as an auxiliary solvent (Table 2). The $\mathrm{Pt} / \mathrm{C}$ catalyzed $\mathrm{H}-\mathrm{D}$ exchange reaction of capric acid $(0.25 \mathrm{mmol})$ in $i-\mathrm{PrOH} / \mathrm{D}_{2} \mathrm{O}$ (each $0.5 / 2 \mathrm{~mL}$ ) at $120^{\circ} \mathrm{C}$ proceeds sufficiently to give the corresponding multideuterium-labeled capric acid with high D contents (Table 2, entry 1). During the H-D exchange reaction, a small amount of capric acid isopropoxy ester is generated as a side product. Therefore, the deuterated capric acid is isolated after hydrolysis of the corresponding isopropyl ester under basic aqueous conditions at $70^{\circ} \mathrm{C}$. The increment of $\mathrm{D}_{2} \mathrm{O}$ (from $2 \mathrm{~mL}$ to $3 \mathrm{~mL}$ ) improved the $\mathrm{D}$ efficiency to around a $95 \% \mathrm{D}$ content (entry 2). Alternatively, isopropanol- $d_{8}\left(i\right.$-PrOD $\left.-d_{8}\right)$ without hydrogen atoms within the molecule is an adequate co-solvent of $\mathrm{D}_{2} \mathrm{O}$ to obtain the almost perfectly deuterium-incorporated capric acid in $96 \%$ isolated yield (entry 3 ). The decrease in $i$-PrOD- $d_{8}$ use resulted in a reduction in the $\mathrm{D}$ contents (entries 4 and 5 ), and furthermore the reaction conditions without $i$-PrOD- $d_{8}$ and the addition of $\mathrm{CD}_{3} \mathrm{OD}$ instead of $i$-PrOD- $d_{8}$ were inadequate for the $\mathrm{H}-\mathrm{D}$ exchange reaction (entries 6 and 7).

Various fatty acids are effectively deuterium-labeled in the presence of $\mathrm{Pt} / \mathrm{C}$ in an $i$-PrOD- $d_{8} / \mathrm{D}_{2} \mathrm{O}$ mixed solvent (Chart 13). A substrate bearing a ketone function within the molecule also undergoes deuteration without reduction of the ketone, and pentadecanedioic acid as the dicarboxylic acid substrate can also be transformed into the corresponding deuterated product. Bioactive valproic acid as a secondary carboxylic

$$
\begin{array}{ll}
\text { substrate } & 10 \% \mathrm{Pt} / \mathrm{C}(8 \mathrm{~mol} \%) \\
(0.25 \mathrm{mmol}) & i-\operatorname{PrOD}-d_{8} / \mathrm{D}_{2} \mathrm{O}(0.5 / 2 \mathrm{~mL}) \\
& 120^{\circ} \mathrm{C}, 24 \mathrm{~h} \text { then hydrolysis }{ }^{\mathrm{a})}
\end{array}
$$

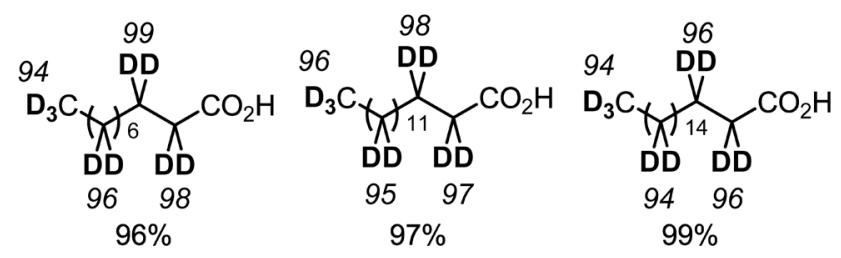

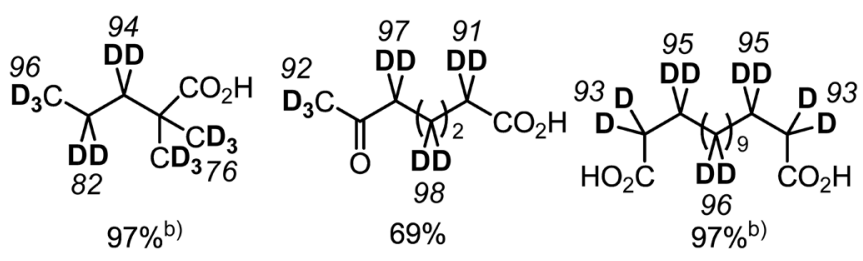

a) Isolated after hydrolysis of the generated isopropyl ester using 5 equiv. of $\mathrm{NaOH}$ at $70^{\circ} \mathrm{C}$ for $24 \mathrm{~h}$.

b) $15 \mathrm{~mol} \%$ of $10 \% \mathrm{Pt} / \mathrm{C}$ was used.

Chart 13. Scope of Substrates for Deuteration of Saturated Fatty Acids

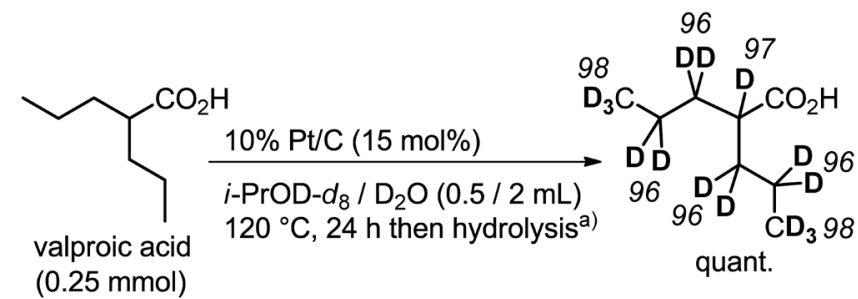

$(0.25 \mathrm{mmol})$

a) Isolated after hydrolysis of the generated isopropyl ester using 5 equiv. of $\mathrm{NaOH}$ at $70^{\circ} \mathrm{C}$ for $24 \mathrm{~h}$.

previously reported

deuterium-labeled valproic acids

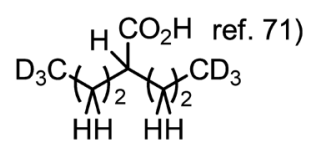

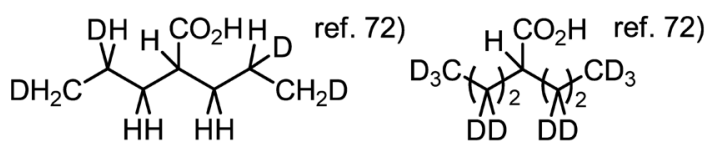

Chart 14. Direct Multi-deuteration of Valproic Acid

acid is also effectively and directly deuterated at all carbons to give fully deuterated valproic acid with excellent D contents and a quantitative isolated yield (Chart 14). While two types of partially deuterium-labeled valproic acids were previously prepared using the total synthetic pathways starting from small deuterium-labeled precursors and applied to the investigation of pharmacokinetics, ${ }^{71,72)}$ the present deuteration method enables the direct synthesis of fully deuterated valproic acid.

\section{Summary and Outlook}

We introduced the platinum group metal on carbon-catalyzed deuterium-labeling method of sugars, arenes, and saturated fatty acids using $\mathrm{D}_{2} \mathrm{O}$ as the cheapest, most readily available deuterium source in this review. Inspired by the different reaction behaviors of the $\mathrm{H}-\mathrm{D}$ exchange reaction between linear alcohols and sterically rigid cyclic alcohols (sugars) under an $\mathrm{H}_{2}$ atmosphere (Section 2), the platinum group metal on the carbon-catalyzed dehydrogenation of alcohols has also been developed. Additionally, the moderately in situ-generated $\mathrm{H}_{2}$ 
by the dehydrogenation of $i-\mathrm{PrOH}$ can be utilized to activate the platinum metal on carbon during $\mathrm{H}-\mathrm{D}$ exchange reactions. The present deuteration methods are very useful and safe to construct various deuterium-labeled arenes and saturated fatty acids because they do not require any external addition of flammable $\mathrm{H}_{2}$ gas resulting in the hydrogenation of reducible functionalities (e.g., ketones and olefins). Further investigations to develop efficient, direct $\mathrm{H}-\mathrm{D}$ exchange reactions of other useful synthetic precursors and bioactive compounds including medicines are currently in progress. We hope that our deuterium-labeling methodologies can contribute to the further development of various scientific fields.

Acknowledgments These studies were partially supported by the Research Foundation for Pharmaceutical Sciences (to Y.S.) and Grants-in-Aid from the Japan Society for the Promotion of Science (15J01556 to T.Y. and 16K15100 to H.S.). Furthermore, we thank the N.E. Chemcat Corporation for the kind gifts of various metal on carbon catalysts.

Conflict of Interest The authors declare no conflict of interest.

\section{References ans Notes}

1) The utilities of the deuterium-labeled compounds were introduced in recent reviews. See refs. 2-6.

2) Atzrodt J., Derdau V., Fey T., Zimmermann J., Angew. Chem. Int. Ed., 46, 7744-7765 (2007)

3) Esaki H., Kurita T., Fujiwara Y., Maegawa T., Monguchi Y., Sajiki H., J. Synth. Org. Chem. Jpn., 65, 1179-1190 (2007).

4) Herbert J. M., J. Labelled Comp. Radiopharm., 53, 658-661 (2010). 5) Sawama Y., Monguchi Y., Sajiki H., Synlett, 23, 959-972 (2012).

6) Sajiki H., J. Pharm. Soc. Jpn., 133, 1177-1193 (2013).

7) Nelson S. D., Trager W. F., Drug Metab. Dispos., 31, 1481-1497 (2003).

8) Schneider F., Hillgenberg M., Koytchev R., Alken R.-G., Arzneim.Forsch./Drug Res., 56, 295-300 (2006).

9) Maltais F., Jung Y. C., Chen M., Tanoury J., Perni R. B., Mani N., Laitinen L., Huang H., Liao S., Gao H., Tsao H., Block E., Ma C., Shawgo R. S., Town C., Brummel C. L., Howe D., Pazhanisamy S., Raybuck S., Namchuk M., Bennani Y. L., J. Med. Chem., 52, 7993-8001 (2009).

10) Sanderson K., Nature (London), 458, 269 (2009).

11) Meanwell N. A., J. Med. Chem., 54, 2529-2591 (2011).

12) Katsnelson A., Nat. Med., 19, 656 (2013).

13) Gant T. G., J. Med. Chem., 57, 3595-3611 (2014).

14) Halford B., Chem. Eng. News, 94, 32-36 (2016).

15) Mullard A., Nat. Rev. Drug Discov., 15, 219-221 (2016).

16) Yamamoto M., Oshima K., Matsubara S., Heterocycles, 67, 353-359 (2006).

17) Ishibashi K., Matsubara S., Chem. Lett., 36, 724-725 (2007).

18) Sajiki H., Hattori K., Aoki F., Yasunaga K., Hirota K., Synlett, $1149-1151(2002)$

19) Ito N., Watahiki T., Maesawa T., Maegawa T., Sajiki H., Adv. Synth. Catal., 348, 1025-1028 (2006).

20) Maegawa T., Fujiwara Y., Inagaki Y., Esaki H., Monguchi Y., Sajiki H., Angew. Chem. Int. Ed., 47, 5394-5397 (2008).

21) Maegawa T., Fujiwara Y., Inagaki Y., Monguchi Y., Sajiki H., $A d v$. Synth. Catal., 350, 2215-2218 (2008).

22) Sawama Y., Yabe Y., Iwata H., Fujiwara Y., Monguchi Y., Sajiki H., Chem. Eur. J., 18, 16436-16442 (2012).

23) Sajiki H., Kurita T., Esaki H., Aoki F., Maegawa T., Hirota K., Org. Lett., 6, 3521-3523 (2004).

24) Koch H. J., Stuart R. S., Carbohydr. Res., 64, 127-134 (1978).
25) Angyal S. J., Stevens J. D., Odier L., Carbohydr. Res., 157, 83-94 (1986).

26) Cioffi E. A., Prestegard J. H., Tetrahedron Lett., 27, 415-418 (1986).

27) Angyal S. J., Stevens J. D., Odier L., Carbohydr. Res., 169, 151-157 (1987).

28) Cioffi E. A., Willis W. S., Suib S. L., Langmuir, 4, 697-702 (1988).

29) Cioffi E. A., Willis W. S., Suib S. L., Langmuir, 6, 404-409 (1990).

30) Földesi A., Nilson F. P. R., Glemarec C., Gioeli C., Chattopadhyaya J., Tetrahedron, 48, 9033-9072 (1992).

31) Cioffi E. A., Tetrahedron Lett., 37, 6231-6234 (1996).

32) Cioffi E. A., Bell R. H., Le B., Tetrahedron Asymmetry, 16, 471-475 (2005).

33) Sawama Y., Morita K., Yamada T., Nagata S., Yabe Y., Monguchi Y., Sajiki H., Green Chem., 16, 3439-3443 (2014).

34) Sawama Y., Morita K., Asai S., Kozawa M., Tadokoro S., Nakajima J., Monguchi Y., Sajiki H., Adv. Synth. Catal., 357, 1205-1210 (2015).

35) Tojo G., Fernandez M., "Oxidation of Primary Alcohols to Carboxylic Acids,” Springer, Berlin, 2007.

36) Mitsudome T., Mikami Y., Funai H., Mizugaki T., Jitsukawa K., Kaneda K., Angew. Chem. Int. Ed., 47, 138-141 (2008).

37) Shimizu K., Sugino K., Sawabe K., Satsuma K., Chem. Eur. J., 15, 2341-2351 (2009).

38) Fang W., Zhang Q., Chen J., Deng W., Wang Y., Chem. Commun., 46, 1547-1549 (2010).

39) Mitsudome T., Mikami Y., Ebata K., Mizugaki T., Jitsukawa K., Kaneda K., Chem. Commun., 46, 4804-4806 (2008).

40) Damodara D., Arundhathi R., Likhar P. R., Adv. Synth. Catal., 356, 189-198 (2014).

41) Shimizu K., Kon K., Seto M., Shimura K., Yamazaki H., Kondo J. N., Green Chem., 15, 418-424 (2013).

42) Kon K., Hakim S. S. M. A., Shimizu K., J. Catal., 304, 63-71 (2013).

43) Shimizu K., Kon K., Shimura K., Hakim S. S. M. A., J. Catal., 300, 242-250 (2013)

44) Sawama Y., Yabe Y., Shigetsura M., Yamada T., Nagata S., Fujiwara Y., Maegawa T., Monguchi Y., Sajiki H., Adv. Synth. Catal., 354, 777-782(2012).

45) Sawama Y., Mori M., Yamada T., Monguchi Y., Sajiki H., Adv. Synth. Catal., 357, 3667-3670 (2015).

46) Sawama Y., Yamada T., Yabe Y., Morita K., Shibata K., Shigetsura M., Monguchi Y., Sajiki H., Adv. Synth. Catal., 355, 1529-1534 (2013).

47) Yamada T., Park K., Yasukawa N., Morita K., Monguchi Y., Sawama Y., Sajiki H., Adv. Synth. Catal., 358, 3277-3282 (2016).

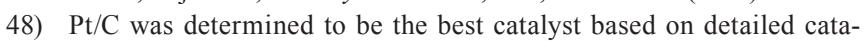
lyst screening. See the original literature (refs. 46 and 47).

49) Bersch B., Starck J. P., Milon A., Nakatani Y., Ourisson G., Bull. Soc. Chim. Fr., 130, 575-583 (1993).

50) Badia A., Cuccia L., Demers L., Morin F., Lennox R. B., J. Am. Chem. Soc., 119, 2682-2692 (1997).

51) Wang H.-S., Ozaki Y., Iriyama K., Langmuir, 16, 5142-5147 (2000). 52) Lorigan G. A., Dave P. C., Tiburu E. K., Damodaran K., Abu-Baker S., Karp E. S., Gibbons W. J., Minto R. E., J. Am. Chem. Soc., 126, 9504-9505 (2004).

53) Vogel A., Katzka C. P., Waldmann H., Arnold K., Brown M. F., Huster D., J. Am. Chem. Soc., 127, 12263-12272 (2005).

54) Gazi E., Gardner P., Lockyer N. P., Hart C. A., Brown M. D., Clarke N. W., J. Lipid Res., 48, 1846-1856 (2007).

55) Schroeter A., Kiselev M. A., Hauß T., Dante S., Neubert R. H. H., Biochim. Biophys. Acta, 1788, 2194-2203 (2009).

56) Rowland M. M., Best M. D., Tetrahedron, 65, 6844-6849 (2009).

57) Darwish T. A., Luks E., Moraes G., Yepuri N. R., Holden P. J., James M., J. Labelled Comp. Radiopharm., 56, 520-529 (2013).

58) Sierra-Hernández M. R., Allen H. C., Langmuir, 26, 18806-18816 (2010). 
59) Gorcea M., Hadgraft J., Moore D. J., Lane M. E., Int. J. Pharm., 435, 63-68 (2012)

60) Jirošová A., Majer P., Jančařík A., Dolejšová K., Tykva R., Šobotník J., Jiroš P., Hanus R., ChemBioChem, 15, 533-536 (2014).

61) Oguri M., Gooris G. S., Bito K., Bouwstra J. A., Biochim. Biophys. Acta, 1838, 1851-1861 (2014).

62) Stiebing C., Matthaus C., Krafft C., Keller A.-A., Weber K. Lorkowski S., Popp J., Anal. Bioanal. Chem., 406, 7037-7046 (2014).

63) Fu D., Yu Y., Folick A., Currie E., Farese R. V. Jr., Tsai T.-H., Xie X. S., Wang M. C., J. Am. Chem. Soc., 136, 8820-8828 (2014).

64) Tuohetahuntila M., Spee B., Kruitwagen H. S., Wubbolts R., Brouwers J. F., van de Lest C. H., Molenaar M. R., Houweling M., Helms J. B., Vaandrager A. B., Biochim. Biophys. Acta, 1851 220-230 (2015)

65) Angelova P. R., Horrocks M. H., Klenerman D., Gandhi S. Abramov A. Y., Shchepinov M. S., J. Neurochem., 133, 582-589
(2015).

66) Thakoersing V. S., van Smeden J., Boiten W. A., Gooris G. S. Mulder A. A., Vreeken R. J., El Ghalbzouri A., Bouwstra J. A., Exp. Dermatol., 24, 669-674 (2015).

67) Brotherton C. A., Wilson M., Byrd G., Balskus E. P., Org. Lett., 17, 1545-1548 (2015)

68) Lichtenecker R. J., Schorghuber J., Bisaccia M., Synlett, 26, 2611$2616(2015)$

69) Yepuri N. R., Jamieson S. A., Darwish T. A., Rawal A., Hook J. M., Thordarson P., Holden P. J., James M., Tetrahedron Lett., 54, 2538-2541 (2013)

70) Yamada T., Sawama Y., Shibata K., Morita K., Monguchi Y., Sajiki H., RSC Adv., 5, 13727-13732 (2015).

71) Acheampong A., Abbott F., Burton R., Biomed. Mass Spectrom., 10, 586-595 (1983)

72) von Unruh G. E., Jancik B. C., Hoffmann F., Biomed. Mass Spectrom., 7, 164-167 (1980). 